\title{
Effects of Demographic Factors on Plantain Production in Southern Part of Edo State, Nigeria.
}

\author{
Egbodion, J. and K. O. Ilavbarhe \\ Department of Agricultural Economics and Extension Services, University of Benin, Benin City, Nigeria.
}

\begin{abstract}
This study examined the effects of demographic factors on plantain production in Edo State, using Ovia Northeast Local Government Area as a case study. Primary data were collected with a multistage sampling procedure. Ten (10) plantain farming communities (Utese, Uhen, Egbeta, Ogbese, Okada, Iguomo, Aghanokpe, Ugbuwe, Ofunwengbe and Ugboke) were purposely selected and fifteen (15) plantain farmers were selected randomly from the communities to get a total of one hundred and fifty (150) respondents. Data were analysed using descriptive and regression statistics.

The Findings revealed that majority (66\%) of the farmers were male, with average farm size of 2.63hectares, mean age of farmers at 40 years, educational level of secondary school, farming experience of between 11 and 20 years respectively.

The regression analysis shows that education level (0.255), marital status (0.149), farm size (0.666) and farming experience (0.603) coefficients were positive, an indication that these variables have direct effect on plantain production in the study area. About $55.7 \%$ variation in the farmers output were explained by the demographic factors which also are confirmed by F-ratio (25.489) that is significant at $\propto$-level of probability. Based on the findings, government should facilitate policies towards education of farmers, subsidize alternatives to labour for farm activities and enhance availability of arable land to plantain farmers in Edo state.
\end{abstract}

\section{Introduction:}

Plantain (Musa ssp.) belongs to the family Musaceae. The crop is widely grown all over the World and its production in Africa is estimated at more than $50 \%$ of the World production (FAO, 1990). Majority (82\%) of the plantain output in Africa are produced in the low land of Guinea, Liberia to the central basin of the Democratic Republic of Congo. About 70 million people in West and Central Africa derives more than $25 \%$ of their carbohydrates from the consumption of plantain, making it one of the major sources of energy in Africa (Swennen, 1990). Food and Agricultural Organisation (FAO, 2007) noted that Nigeria is a major producer of plantain in West and Central Africa and ranked fifth highest producer in the World.

Plantain consumption in Nigeria in different forms is on the increase because of its high nutritional value, implying the existence of increased market potential for its production. However, plantain output (80\%) is left in the hands of subsistence rural farmers (Bayeri, 1996). According to Adesanya, (2008) plantain is consumed in the World today in the form of boiled or roasted, plantain flour, chips and so on. These forms which are widely consumed are rich in protein $(1.2 \%)$, carbohydrate $(35 \%)$ and ash $(0.8 \%)$. It is used in the prevention of kwashiorkor (Idachaba, 1995). The crop ranked third among starchy staples in Nigeria after cassava and yam. It is a major source of carbohydrate to man and domesticated animals. According to Ndubizu, (1995) plantain is said to have advantage of short gestation period of between $14-20$ months with rapid multiplication ability (suckers) and as such several harvest can be made from one planting unlike other permanent crops. It fruits the year round.

Research evidence has shown that plantain cultivation is still largely at the subsistence level within the forest zone of sub - Saharan Africa. The continuous availability of harvested bunches from established plantations makes it possible for the crop to contribute to year round food security and income for farmers. This may be particularly important when seasonal conditions create period of food shortages and other crops are in short supply. The interest of this study premised on the fact that the crop has the capacity to bridge the supply gap of carbohydrate when in high demand especially when other starchy staples are unavailable or difficult to harvest in the dry season. Hence this study focuses on the effects of demographic factors on plantain production in Edo State.

\section{Methodology:}

Study Area: The Study was carried out at Ovia Northeast Local Government Area (LGA) of Edo State. The LGA lies between latitude $6^{0}-6.9^{0} \mathrm{~N}$ and longitude $5.5^{0}-5.9^{0} \mathrm{E}$ in the North, while it extends through longitude $5.5^{0}-5.6^{\circ} \mathrm{E}$ in the South, with a population of about 153,849 people and a land mass of 2, 357, 225 square kilometers, with an annual maximum temperature of $30^{\circ} \mathrm{C}$ and minimum of $22^{\circ} \mathrm{C}$. The annual average 
rainfall is $1700 \mathrm{~mm}$ and a relative humidity of $80-120 \%$. These factors are favourable for plantain cultivation in this area.

Sampling Procedure and Sampling Size: A multistage sampling procedure was adopted to select one hundred and fifty (150) respondents. First, a purposive selection of ten (10) communities noted for plantain cultivation was done, secondly, random selection of fifteen (15) plantain farmers from each of the communities was done and this gave a total size of one hundred and fifty (150) respondents used for the study.

Method of Data Collection: Relevant demographic factor data were collected from the farmers using questionnaire and assisted with personal interview.

Method of data analysis: Descriptive and multiple regression statistics were adopted to analyzed collected data. Descriptive statistics such as mean, percentage and frequency distribution were used to describe the demographic factors of the farmers, while the multiple regression analysis was used to examine the effects of the demographic factors on plantation production in Ovia Northeast Local Government Area of Edo State. Model Specification: Consider a typical plantain farmer with a production function of the form: $\mathrm{Y}=\mathrm{f}\left(X_{1}\right.$ $X_{n}, Z_{1}$ ..$\left.Z_{m}\right)$

Where $Y$ is output, $X$ represent variable inputs and $Z$ represent fixed and other shifter variables of the function Based on the above production function outlined, an empirical model is developed for plantain production in Edo State leaving out variables of less interest to this study as follows:

$\mathrm{Y}=B_{1}+B_{2} X_{1}+B_{3} X_{2}+$ $B_{n} X_{m}$

Where

$\mathrm{Y}=$ Output of plantain in tones/hectares

$B_{1}-B_{n}=$ Regression coefficients

$X_{1}=$ Age (Years)

$X_{2}=$ Farm size (Hectares)

$X_{3}=$ Level of Education (Years of formal schooling)

$' X_{4}=$ Marital status (Single $=0$, Married $\left.=1\right)$

$X_{5}=$ Farming experience (Years)

$X_{6}=$ Age of Farm (Years)

$X_{7}=$ Gender $($ male $=1$, Female $=2)$

\section{Results and Discussion}

The results from the survey of the demographic factors are in conformity with our appriori expectations as showed in table 1. Most of the farmers were between 31-50 years, young which indicate that they are energetic and innovative, with farm size of 2.6hectares and on the average had farms of 8 years old which also indicated that the farmers were small scale farmers.

Majority $(66 \%)$ of the farmers were male, with average farming experience of 10years; an indication that farming requires strength and that the male folk have easier access to farmland than the women. About $44 \%$ of the farmers were married with children, an indication that the farmers have access to family labour. These findings agree with Oladeji and Oyesola (2000), Barmeke and Omoregbe (2009) findings who stated that most farmers are married and that they have access to family labour.

The result further showed that majority of the farmers $(66.7 \%)$ had formal education an indication that the farmers can adopt new innovation of farming if introduced to the study area.

Table 1.0:Demographic factors of farmers.

Source: Survey data, 2012 .

\begin{tabular}{|l|l|}
\hline Demographic factor & Mean \\
\hline Age of farmers (years) & 40.5 years \\
\hline Gender & $66 \%$ (Male), 34\% (Female) \\
\hline Marital status & $54 \%$ (married), unmarried $(46 \%)$ \\
\hline Education level & $66.7 \%$ formal education \\
\hline Farm size & 2.63 hectares \\
\hline Age of Farm (years) & 8 years \\
\hline
\end{tabular}

The regression analysis presented in table 2.0 showed that the coefficient of education had $(0.225)$, marital status (0.149), farm size (0.660) and (0.003) farming experience had positive signs; an indication that these variables have direct implication for plantain production in the study area. However, Educational level, marital status and farm size were the significant demographic factors in the study area. This result agrees with our appiori expectation for the study.

The adjusted $\mathrm{R}^{2}$ which show goodness of fit of the model indicated that about $55.7 \%$ of the output variation of the farmers was explained by their demographic factors. This result was also confirmed by the FStatistics 25.489 ) to be significant at $5 \%$ level of probability. 
Table 2.0: Regression analysis result.

\begin{tabular}{|l|l|l|}
\hline Variables & Coefficient & t-ratio \\
\hline Constant & -7517.824 & -2.088 \\
\hline Gender & -0.470 & -0.786 \\
\hline Age & -0.100 & -1.101 \\
\hline Educational level & $0.255^{* *}$ & 3.816 \\
\hline Marital Status & $0.147^{* *}$ & 2.337 \\
\hline Age of farm & -0.005 & -0.082 \\
\hline Size of farm & $0.660^{* *}$ & 11.432 \\
\hline Farming experience & 0.003 & 0.0028 \\
\hline
\end{tabular}

** $\quad$ Significant at $5 \%$ level of probability

Adjusted $\mathrm{R}^{2}=0.557, \mathrm{f}$-Statistics $=25.489 * *$

Source: field survey, 2012.

\section{Conclusion And Recommendation}

The study employed multiple regression analysis to examine the relationship between farmers' socioeconomic characteristics and their output in the study area. The empirical evidence revealed that $55.7 \%$ variation in output of farmers were mostly determined by educational level of farmers, marital status and size of the plantain farms; since these factors were the significant variables affecting the production of plantain in the study area.

The implication of this finding is that any effort aimed at increasing the size of farms, building the educational capacity of these farmers and providing incentives to better the lots of these farmers' families will increase and improve the output of their farms and standard of living. This study therefore recommends mass literacy campaign targeted towards plantain farmers and the need for organs of government to make policies that will allow plantain farmers access to farmland that will increase their farm sizes in the study area and enhance increased plantain production in the study area.

\section{References}

[1]. Baruwa, O.I., Masuku, M.B. and Alimis, T. (2011). Economic analysis of plantain production in Derived Savannah Zone of Osun State, Nigeria. Agricultural Economic Department, Faculty of Agriculture, ObafemiAwolowo University, Ile-Ife, Osun State asian Journal of Agricultural Science 2(5)401-407

[2]. Bayeri K.P. (1996): Characterization, Correlation path analysis and selection indices of Musa genotype under nuclear different conditions. University of Nigeria, Nsukka. Pp 1-8

[3]. Banmeke, T. O. A. and Omoregbee (2009) Farmers' Perception of the Factors Militating Against Rubber Production in Edo and Delta States of Nigeria. Intern. Journal of Agricultural Economics \& Rural Development2(2) Pp 33 - 39

[4]. FAO Agrostat Database (2004) Food and Agriculture Organisation of the United Nations, production year book. FAO, Rome.

[5]. Idachaba, F.S. (1995) Food policy in Nigeria towards a framework analysis Agricultural research bulletin in Vol. 77 (1).

[6]. Ndubizu, T.O.C. (1985) Plantain production manual for Nigerian Growers Association. A paper presented at the first National workshop on fruit production in Nigeria by Federal Agricultural Coordinatig Unit, NIHORT FACU conference hall, Ibadan $14^{\text {th }}-$ $16^{\text {th }}$.

[7]. Ogazi, P.O. (1996): Plantain Production Processing Utilisation, Pama and Associates Ltd, Uku, Ogwe.

[8]. Olatundun, B.E. (2002). Resource Productivity in small scale farming: A case study in selected three local government area in Kwara State.

[9]. Swennen, R. (1990) Plantain cultivation under West African condition. A Reference Manual, Amarin printing group co. Bangkok.

[10]. Wilson, G.F. (1986), Status of Banana and Plantain in West Africa proc. Workshop on Banana and Plantain Breeding Strategies. Cairns, Australia 13-17 October, Pp29-31.

[11]. Oladiji, J.O. and Oyesola, O.B. (2000).Information needs of Rice Farmers on Harvesting and Processing activities in Oba Femi Owode Local Government Area, Ogun State, Nigeria Pp.144-150. 